\title{
Artikel
}

\section{Vaart de notaris tuchtrechtelijk op het kompas van de verkopende executeur? In het algemeen wel, nu niet!}

Prof. mr. dr. B.M.E.M. Schols*

\section{De prelude voor de kamer voor het notariaat}

De notaris die geconfronteerd wordt met een verkopende beheersexecuteur moet zich de vraag stellen in hoeverre hij mag meewerken aan door de executeur zonder medewerking van de erfgenamen te verrichten rechtshandelingen. Deze vraag kwam an de orde bij de Kamer voor het notariaat Arnhem-Leeuwarden op 27 maart 2015, ECLI:NL:TNORARL:2015:30 en in hoger beroep bij Hof Amsterdam op 22 december 2015, ECLI:NL:GHAMS:2015:5551. En bij beantwoording van de eerste vraag lopen wij automatisch tegen de navolgende vraag aan: is de executeur (civielrechtelijk) zelfstandig bevoegd om namens de erfgenamen een onroerende zaak te verkopen en te leveren? ${ }^{1}$

De casus, of wellicht beter: het erfrechtelijk drama, speelde zich af in het noorden van het land. De beheersexecuteur gaat over tot verkoop en levering van een landgoed. Op zich nog niet bijzonder, ware het niet dat de erfgenamen hebben laten weten dat zij het landgoed

* Prof. mr. dr. B.M.E.M. Schols is als hoogleraar verbonden aan het Centrum voor Notarieel Recht van de Radboud Universiteit Nijmegen en is tevens vennoot bij ScholsBurgerhartSchols.

1. Zie hierover Hof Arnhem-Leeuwarden 6 oktober 2015, ECLI:NL: GHARL:2015:7486, welk arrest ik analyseerde in B.M.E.M. Schols, Mag de executeur verkopen, of niet?, FTV 2016/7. Thans zal ik de klemtoon leggen op de tuchtrechtelijke kant van de zaak, oftewel de rol van de notaris. Uiteraard ontkomen we ook hierbij niet aan de civielrechtelijke problematiek. graag in de familie wilden houden. De executeur ${ }^{2}$ zet zijn wil echter door, waarbij niet onvermeld mag blijven dat de notaris in de considerans van de koopovereenkomst de navolgende frase over een 'ontsnappingsclausule' heeft opgenomen:

'd. dat koper kennis heeft genomen van de discussies welke de ondergetekende sub 1 heeft gevoerd met de erfgenamen van erflater, reden waarom zij akkoord gaan met de hierna onder artikel 15 lid 4 van deze akte genoemde bevoegdheid van verkoper om deze koopovereenkomst te ontbinden, wanneer een rechterlijke uitspraak haar daartoe mocht noodzaken, zulks uitsluitend ter harer beoordeling'.

De toon is met het opnemen van deze clausule behoorlijk gezet. Op 23 april 2013 wordt door notaris X de koopakte opgesteld en op 1 mei daarop volgend wordt reeds door notaris $\mathrm{Y}$ van hetzelfde kantoor de akte van levering gepasseerd.

In de koopovereenkomst is vermeld dat tot de nalatenschap diverse schulden behoren die naar het oordeel van de executeur niet kunnen worden voldaan zonder diverse goederen behorende tot de nalatenschap te gelde te maken. De erfgenamen hebben laten weten dat zij hun erfrechtelijke vorderingen die zij hebben op hun overleden vader ter zake van het eerdere overlijden van hun moeder thans niet zullen opeisen (staat in de procedure bij het hof vast).

2. Nomen est (weliswaar) omen, maar dat wil uiteraard niet zeggen dat een executeur misbruik mag maken van het aan hem verleende vertrouwen. 
In de (bij mijn weten niet-gepubliceerde) civielrechtelijke uitspraak van de rechtbank van 26 februari 2014, waarvan het dictum kenbaar is uit het in hoger beroep gewezen arrest van 6 oktober 2015, wordt de executeur veroordeeld tot vergoeding van de nader bij staat op te maken schade die de erfgenamen lijden doordat de executeur het landgoed te gelde heeft gemaakt. ${ }^{3}$ De vordering voor recht te verklaren dat er vanwege beschikkingsonbevoegdheid van de executeur geen rechtsgeldige levering heeft plaatsgehad, wordt in eerste aanleg door de rechtbank afgewezen.

Van belang is nog te vermelden dat de executeur in de uiterste wil was vrijgesteld van de overlegverplichting als bedoeld in artikel 4:147 lid 2 van het Burgerlijk Wetboek (BW):

'De executeur behoeft over de keuze en de tegeldemaking van de door haar beheerde goederen van de nalatenschap niet in overleg te treden met de erfgenamen en hun toestemming daarvoor is ook niet vereist.'

Om in de tuchtrechtelijke sfeer te komen allereerst een blik op de hiervoor aangestipte uitspraak van de Kamer voor het notariaat Arnhem-Leeuwarden van 27 maart 2015. Aanleiding voor deze uitspraak was een klacht tegen de notarissen die betrokken waren bij de verkoop en levering van het landgoed door de executeur aan een derde. De eerste klacht kwam erop neer dat de notarissen niet aan de voorbereiding van de eigendomsoverdracht hadden mogen meewerken omdat de erfgenamen het hier niet mee eens waren. De tweede klacht richtte zich op het feit dat de akte van levering ook niet gepasseerd had mogen worden, zeker nu zij op de hoogte waren van het door klagers ingediende verzoek tot schorsing van de executeur. Op de dag van de levering werd de executeur geschorst. In het verlengde van deze klachten stellen de erfgenamen ook dat de notarissen hadden dienen af te zien van de doorbetaling van de verkoopopbrengst aan de executeur. Ter zitting is komen vast te staan dat de notaris die de levering heeft gepasseerd geen bemoeienis heeft gehad met de afhandeling van de zaak en dat het de andere notaris is geweest (die ook de koopakte heeft opgesteld) die de verkoopopbrengst heeft doorbetaald. In zoverre valt de notaris die de koopsom niet heeft doorbetaald ertussenuit.

De kamer was relatief snel klaar met de kwestie en legt de klemtoon op het feit dat de executeur ervan uitging en er ook van uit kon gaan dat klagers aanspraak maakten op het erfdeel uit de nalatenschap van hun moeder. Zo heeft de notaris onder meer het volgende e-mailbericht verstuurd:

'Wellicht ten overvloede meld ik u beiden dat de executeur, krachtens het testament van erflater, over de

3. De executeur wordt eveneens veroordeeld in de proceskosten van de erfgenamen. De erfgenamen worden veroordeeld in de proceskosten van de verkrijgers (in conventie), met dien verstande dat de verkrijgers in de proceskosten van de erfgenamen worden veroordeeld (in reconventie). keuze en te gelde making van de door haar beheerde goederen van de nalatenschap niet in overleg behoeft te treden met de erfgenamen en dat ook hun toestemming niet is vereist. $\mathrm{Nu} u$ beiden niet akkoord gaat met de voorstellen van mevrouw $[\mathrm{F}]$ en haar zoon, de heer $[\mathrm{G}]$, en bovendien ook niet inhoudelijk hierop reageert, noch met tegenvoorstellen komt, achten zij zich vrij om te handelen zoals een goed executeur betaamt, waarbij u verder zult begrijpen dat zij, teneinde te kunnen voldoen aan de schulden van de nalatenschap, wel gedwongen zijn (mede) over te gaan tot verkoop van de woning van erflater.'

Het bezwaar van de klagers tegen de verkoop is in de ogen van de kamer te laat, pas na de koop, gemaakt. Voor zich spreekt de navolgende passage. Men zou bijna geneigd zijn om te zeggen dat de kamer de notaris een schouderklopje geeft:

'De kamer acht verder van belang dat notaris [C] in de tekst van de koopovereenkomst aandacht heeft willen schenken aan de bestaande verschillen van inzicht tussen de executeur en klagers. Uit de clausule opgenomen onder artikel 2 punt $d$ van deze overeenkomst volgt dat notaris [C] hiervoor in de koopovereenkomst een voorziening heeft opgenomen. Verder acht de kamer het zorgvuldig dat notaris [C], zoals uit het voorgaande volgt, klagers telkens wel onmiddellijk van (voorgenomen) acties van de executeur in kennis heeft gesteld. De handelwijze van notaris [C] terzake de koopovereenkomst/levering van het landgoed is voldoende zorgvuldig geweest. De klacht dient daarom op dit onderdeel ongegrond te worden verklaard.'

En wat de andere notaris betreft, notaris [D] die de akte van levering heeft gepasseerd, klonk het oordeel als volgt:

'Uit het voorgaande volgt reeds dat notaris [D] er van uit mocht gaan dat met betrekking tot het landgoed een geldige koopovereenkomst gesloten was door een beschikkingsbevoegde executeur, die op grond daarvan tot leveren verplicht was.' (curs. BS)

Verplicht was! En het ingediende verzoek tot schorsing dan?

'(...) Zoals hiervoor al is overwogen, was sprake van een geldige koopovereenkomst en was de executeur beschikkingsbevoegd. Verkoopster en kopers wensten de overdracht. Derhalve was de notaris ondanks de aankondiging van het ingediende schorsingsverzoek gerechtigd zo niet verplicht de akte van levering te passeren. Een en ander brengt de kamer tot de conclusie dat notaris [D] tuchtrechtrechtelijk niet verweten kan worden de akte van levering van 1 mei 2013 gepasseerd te hebben. Dit klachtonderdeel treft daarom geen doel.' (curs. BS)

Zo niet verplicht ... 
Resteert alleen nog de klacht van het uitboeken van de restantkoopsom:

'Vaststaat dat de beschikking tot schorsing van de executeur bij het notariskantoor is ingekomen op 1 mei 2013, om 16.10 uur. Met klagers moet geoordeeld worden dat de notaris geacht moet worden vanaf 1 mei 2013 van de schorsing van de executeur op de hoogte te zijn geweest of dat redelijkerwijze had behoren te zijn en om die reden had behoren af te zien van doorbetaling van (het restant van) de verkoopopbrengst aan de geschorste executeur. De omstandigheid dat de schorsingsbeslissing niet expliciet uitvoerbaar bij voorraad is verklaard brengt hierin geen verandering; immers notaris [C] had alleen al op grond van de schorsingsbeschikking rekening moeten houden met de mogelijkheid dat de (voormalig) executeur uiteindelijk geen (volledige) aanspraak op uitbetaling van de (restant)verkoopopbrengst zou blijken te hebben. In afwachting van duidelijkheid op dat punt had notaris [C] bedoeld bedrag in depot dienen te houden op zijn derdengeldenrekening. De klacht wordt daarom op dit onderdeel gegrond geoordeeld en terzake wordt het opleggen van de maatregel van waarschuwing aan notaris [C] passend en geboden geacht.' (curs. BS)

Duidelijk, al met al valt het voor de notarissen op het niveau van het opstellen van de koopovereenkomst en het passeren van de akte van levering mee.

Klagers gingen in hoger beroep, maar voordat Hof Amsterdam op 22 december 2015 een mening kon geven over het handelen van de notarissen, was daar eerst nog het (civielrechtelijk!) arrest van Hof Arnhem-Leeuwarden van 6 oktober 2015, dat de kwestie toch behoorlijk op scherp zette. Let op de datum. Het civielrechtelijk arrest (in dezelfde zaak) was van 6 oktober 2015 en de tuchtrechtelijke zitting van Hof Amsterdam op 15 oktober 2015. Het arrest zat nog niet in het dossier! Wat nu? Het had eigenlijk tien kalenderdagen voor de zitting van het hof binnen moeten zijn:

'Op de zitting hebben de notarissen bezwaar gemaakt tegen toelating van het eerdergenoemde arrest van 6 oktober 2015. Hierop heeft het hof beslist dat klagers het arrest niet eerder konden toezenden en dat de inhoud bij kennisneming eenvoudig is te doorgronden, zodat het hof het arrest zal toelaten en in het procesdossier zal voegen. Vervolgens heeft het hof aan de notarissen de gelegenheid gegeven het arrest te lezen.' (curs. BS)

We lezen en huiveren met de notarissen mee, maar maken - om goed beslagen ten ijs te komen - eerst nog een rondje langs de Hoge Raad, de wet, de parlementaire geschiedenis en de doctrine. Want zo eenvoudig te doorgronden is het ook weer niet.

\section{HR 21 november 2008, rechtsoverweging 4.2}

De Hoge Raad heeft op 21 november 2008, ECLI:NL:HR:2008:BD5958, een beschouwing gegeven over de ware aard van de executeur. De erfrechtelijke fijnproevers weten dat ik dan doel op de in rechtsoverweging 4.2 opgenomen code voor executeurs: ${ }^{4}$

'4.2 De executeur aan wie, zoals hier het geval is, het bezit van de goederen van de nalatenschap is toegekend en die is aangesteld tot beredderaar van de boedel, is bevoegd met uitsluiting van anderen het beheer over de goederen van de nalatenschap te voeren. Op grond van deze bevoegdheid mag hij het beheer naar eigen inzicht voeren en de keuzes maken die hem ten behoeve van dat beheer geraden voorkomen, zij het dat hij daarbij de zorg van een goed executeur moet betrachten. Hij is bevoegd om goederen van de nalatenschap te verkopen ten behoeve van de afwikkeling van de nalatenschap, bijvoorbeeld teneinde een schuld uit een legaat of een (andere) schuld van de nalatenschap te voldoen.' (curs. BS)

De Hoge Raad breidt de verkoopbevoegdheid van de executeur uit via de navolgende gedachte:

'Voor de aan het beheer te ontlenen bevoegdheden kan voorts aansluiting worden gezocht bij art. 3:170 lid $2 \mathrm{BW}$, volgens welke bepaling onder beheer begrepen zijn alle handelingen die voor de normale exploitatie van het goed dienstig kunnen zijn; dit omvat ook daden van beschikking die door een normale exploitatie van het goed worden gevorderd (vgl. Parl. Gesch. Boek 3, blz. 581). Ook op deze grond kan de executeur derhalve bevoegd zijn tot verkoop van onder zijn beheer vallende goederen. Met betrekking tot een aandelenportefeuille kan dit de bevoegdheid meebrengen de samenstelling daarvan te wijzigen, of de portefeuille te verkopen teneinde de opbrengst op andere wijze te beleggen, een en ander bijvoorbeeld met het oog op een beter rendement dan wel het beperken van koersrisico's.' (curs. BS)

\section{De wet en de parlementaire geschiedenis}

Voorts is wat de vertegenwoordigingsbevoegdheid van de executeur betreft van belang de in artikel 4:145 lid 2 BW opgenomen regel:

4. Om de ware aard van de executeur te vinden, had ik wat meer pagina's nodig, B.M.E.M. Schols, Van exécuteur testamentaire tot Testamentsvollstrecker tot afwikkelingsbewindvoerder. Zijn ware aard. Een onderzoek naar de grondslag van de executele als erfrechtelijke verbintenis (diss. Nijmegen), Deventer: Kluwer 2007. 
'Gedurende zijn beheer vertegenwoordigt hij bij de vervulling van zijn taak de erfgenamen in en buiten rechte.'

Een kant-en-klare reden om goederen van de nalatenschap te verkopen vinden wij in artikel 4:147 BW:

' 1 . De executeur is bevoegd door hem beheerde goederen te gelde te maken, voor zover dit nodig is voor de tot zijn taak behorende voldoening van schulden der nalatenschap en de nakoming der hem opgelegde lasten.

2. Tenzij de erflater anders heeft beschikt, treedt de executeur omtrent de keuze van de te gelde te maken goederen en de wijze van tegeldemaking zoveel mogelijk in overleg met de erfgenamen en stelt hij, zo bij een erfgenaam bezwaar bestaat tegen een voorgenomen tegeldemaking, die erfgenaam in de gelegenheid de beslissing van de kantonrechter in te roepen.

3. De erflater kan bepalen dat de executeur voor de tegeldemaking van een goed de toestemming van de erfgenamen behoeft. Deze toestemming kan echter vervangen worden door een machtiging van de kantonrechter.

4. Het in de vorige leden ten aanzien van de erfgenamen bepaalde geldt mede ten aanzien van hen aan wie het vruchtgebruik van de nalatenschap of van een aandeel daarin is vermaakt.'

In het wetgevingsproces heeft dit artikel een belangrijke metamorfose ondergaan, die bij de onderhavige problematiek een cruciale rol speelt dan wel zou kunnen spelen. Aan bovenstaande spelregels was immers in eerste instantie nog het volgende lid toegevoegd: ${ }^{5}$

'5. Heeft de executeur een rechtshandeling in strijd met het in dit artikel bepaalde verricht, dan kan, indien de mederpartij dit wist, degene jegens wie de overtreding is begaan, de rechtshandeling vernietigen binnen een jaar nadat zij te zijner kennis is gekomen.' (curs. BS)

Let pel: deze vernietigingsmogelijkheid (lid 5) is in het wetgevingsproces gesneuveld met de navolgende toelichting: ${ }^{6}$

'In het licht van de vanuit de commissie gemaakte opmerking achtte de Regering het raadzaam, bedoeld vijfde lid uit de tekst van het ontwerp te laten vervallen, ten einde stroefheid door al te grote voorzichtigheid, bij voorbeeld van de zijde van banken die waarden van de nalatenschap onder zich hebben, te voorkomen. Een wezenlijke lacune ontstaat daardoor niet. De bedoeling zat slechts voor, duidelijk kenbare nietoirbare handelingen te bestrijden. Met het oog daarop behoudt men, bij een wegvallen van het onderwerpelijke voorschrift, de actie uit onrechtmatige daad.' (curs. BS)
En dan nog een blik op de literatuur.

\section{De doctrine}

De visie van collega Perrick over de onderhavige problematiek in de erfrechtelijke 'Asser' mag in dezen zeker niet ontbreken en geeft de achtergrond van de problematiek goed weer: ${ }^{7}$

'De executeur behoeft van zijn bevoegdheid tot verkoop niet jegens derden te doen blijken. In de terminologie van het rechtspersonenrecht: op de uit de wet en de uiterste wil voortvloeiende beperkingen kan door of tegen derden geen beroep worden gedaan. In weer andere bewoordingen: deze beperkingen hebben uitsluitend interne werking. Een externe werking zou de uitoefening door de executeur van zijn tak verlammen. Hoe kan een derde beoordelen of de verkoop nodig is voor de voldoening van de schulden van de nalatenschap?'

Met als antwoord:

'De wederpartij van de executeur zal zich niet hoeven te verdiepen in de vraag of het om een tegeldemaking ten behoeve van de schulden van de nalatenschap gaat.'

Helder. Samenvattend, mede gezien de wettekst, parlementaire geschiedenis, jurisprudentie en doctrine: extern heeft de executeur een vergaande vertegenwoordigingsmacht en kan hij door zijn handelen bij de afwikkeling van de nalatenschap de erfgenamen binden. Intern moet de executeur zorgvuldig handelen en een reden hebben om de goederen van de nalatenschap te gelde te maken, bijvoorbeeld (echter met name) de voldoening van schulden van de nalatenschap. Aangezien een executeur naar eigen inzicht kan handelen en de keuzes kan maken die hem bij de afwikkeling van de nalatenschap geraden voorkomen, heeft een derde nagenoeg geen onderzoeksplicht in dezen en mag een derde redelijkerwijs aannemen dat het wel om een tegeldemaking van de schulden van de nalatenschap zal gaan.

En toen werd het 6 oktober 2015. Tijd voor de civielrechtelijke voorfase van het tuchtrechtelijke arrest van 22 december 2015.8

7. Asser/Perrick 4 2013/696. Zie ook W. Breemhaar, De uiterste wilsbeschikking (diss. Groningen), Deventer: Kluwer 1992, p. 167-168 en B.M.E.M. Schols e.a., Handboek erfrecht, Deventer: Kluwer 2015, XIV, nr. 5.4.

8. Hof Amsterdam 22 december 2015, ECLI:NL:GHAMS:2015:5551. 


\section{Analyse Hof Arnhem- Leeuwarden 6 oktober 2015}

De casus die leidde tot het civielrechtelijke arrest van Hof Arnhem-Leeuwarden van 6 oktober 2015, ECLI:NL:GHARL:2015:7486 heb ik in de inleiding reeds kort geschetst. De kwestie is terug te brengen tot de vraag of een executeur een onroerende zaak te gelde mag maken, oftewel de erfgenamen kan binden zonder dat er schulden van de nalatenschap hoeven te worden voldaan. Kunnen de kopers de erfgenamen aan de door de executeur als vertegenwoordiger gesloten koopovereenkomst houden? En is door de levering de eigendom van het landgoed overgegaan?

De eerste stap die door het hof wordt gezet, is, onder verwijzing naar artikel 3:89 $\mathrm{BW}$ in verbinding met artikel 3:84 BW, waarin de voor de overdracht van registergoederen gestelde vereisten zijn opgenomen, te onderzoeken of de executeur de erfgenamen heeft gebonden aan de koop met betrekking tot het landgoed. Vervolgens wordt een beschouwing gegeven over de taak van de executeur:

'15. Voorop gesteld moet worden dat [appellant 3] als executeur ingevolge het bepaalde in art. 4:145 BW tot taak had om de in art. 4:7 BW bedoelde schulden van de nalatenschap te voldoen, die tijdens haar beheer uit de goederen van de nalatenschap behoren te worden voldaan, en met het oog daarop de goederen van de nalatenschap te beheren, nu de erflater in zijn uiterste wil niet anders heeft beschikt. Gedurende haar beheer was [appellant 3] bevoegd om [appellanten] bij de vervulling van haar taak in of buiten rechte te vertegenwoordigen.

16. Eerder bedoelde schulden behoren blijkens de wetsgeschiedenis, in het algemeen gesproken, door de executeur uit de goederen van de nalatenschap te worden voldaan, voor zover die schulden bij de aanvang van zijn beheer opeisbaar zijn of tijdens zijn beheer worden (vgl. Parl. Gesch., Boek 4, p. 845, laatste alinea, en p. 848, eerste volledige alinea). Voor hetgeen onder beheer is te verstaan kan aansluiting worden gezocht bij het bepaalde in art. 3:170 lid 2, tweede zin, BW (HR 21 november 2008, ECLI:NL:HR:2008:BD5985, rechtsoverweging 4.2), zodat in het kader van het beheer van een nalatenschap door een executeur als een daad van beheer kan worden aangemerkt iedere handeling die voor een normale exploitatie van de goederen van de nalatenschap dienstig is.'

En hoe kan een derde een en ander beoordelen?

'17. Aangezien het voor een derde in het algemeen moeilijk zal zijn om te beoordelen of het beheer een bepaalde handeling vordert, wordt blijkens de wetsgeschiedenis met het oog op de positie van derden in art. 3:170 BW lid 2, tweede zin, BW gesproken van handelingen die voor een normale exploitatie dienstig kunnen zijn (zie Parl. Gesch., Boek 3, p. 588), zodat een derde een executeur tot het verrichten van een bepaalde handeling bevoegd kan achten, indien hij redelijkerwijs mag aannemen dat het om een daad van beheer gaat.

18. In het verlengde van art. 4:145 BW heeft ingevolge het bepaalde art. 4:147 BW een executeur die de in art. 4:145 BW omschreven taak heeft, de bevoegdheid om de goederen van de nalatenschap te gelde te maken, voor zover dit nodig is voor de voldoening van de in art. 4:7 BW bedoelde schulden van de nalatenschap die tijdens zijn beheer daaruit behoren te worden voldaan. Aangezien het voor een derde in het algemeen moeilijk zal zijn om te beoordelen, of de tegeldemaking van een goed van de nalatenschap daarvoor nodig is, ligt het voor het antwoord op de vraag, of een derde een executeur tot de tegeldemaking van een goed van de nalatenschap bevoegd kan achten, voor de hand om daarvoor aansluiting te zoeken bij hetgeen voor het beheer van een nalatenschap door de executeur in het algemeen geldt (zie hiervoor rechtsoverweging 17). Het hof zal daarom voor de vraag of koper de executeur bevoegd konden achten om het landgoed te gelde te maken, beslissend achten of zij redelijkerwijs mochten aannemen dat de tegeldemaking in de hiervoor bedoelde zin nodig was.'

Cruciaal is derhalve of de koper redelijkerwijs mocht aannemen dat tegeldemaking (bijvoorbeeld) nodig was om schulden van de nalatenschap te voldoen. Merk op dat het hof spreekt van 'derde in het algemeen', 'redelijkerwijs' en 'kunnen zijn', met een cursivering van het woordje kunnen. Dit maakt de toetsing van de bevoegdheidsvraag minder streng, minder wiskundig, en heel marginaal.

Vervolgens onderzoekt het hof de omstandigheden waaronder de koopovereenkomst tot stand is gekomen, waarbij het hof vooropstelt dat de noodzaak van het te gelde maken te dezen ontbrak, omdat appellanten, naar vaststaat:

'alsnog hadden afgezien van de opeising van hun moederlijke erfdeel, terwijl niet is gebleken dat de voldoening van andere, in art. 4:7 $\mathrm{BW}$ bedoelde schulden van de nalatenschap die tegeldemaking nodig maakte'.

Het hof leidt uit verklaringen van kopers af dat zij op het kompas van de notaris zijn gevaren waar het gaat om de verkoopbevoegdheid van de executeur. Wat gaf dit kompas dan aan? Dat de notaris:

'22. (...), zoals kan worden afgeleid uit hetgeen vaststaat, zodanig op de hoogte [was] van de nalatenschap, dat het er, naar het oordeel van het hof, voor moet worden gehouden dat hij wist dat [appellanten] het landgoed wensten te behouden en in verband daarmee van opeising van hun moederlijk erfdeel alsnog hadden afgezien.' 
Voor zover de notaris geacht wordt te zijn opgetreden ten behoeve van de kopers wordt de wetenschap van de notaris aan hen toegerekend en komt dit voor rekening van kopers in verhouding tot de erfgenamen. Het hof stelt zich ook de vraag hoe het zou zijn als de notaris niet kan worden geacht voor de kopers te zijn opgetreden. Dan zouden ze volgens het hof ook niet op zijn kompas kunnen varen wat het onderhavige bevoegdheidsvraagstuk betreft. De spanning stijgt. En hoe zou het dan aflopen? Dan:

'bestond er alleszins aanleiding voor hen om, gelet op de inhoud van het koopcontract, meer in het bijzonder de preambule, alvorens de koopovereenkomst aan te gaan zelfstandig een nader onderzoek in te stellen, c.q. te doen instellen met betrekking tot de bedoelde bevoegdheid van de executeur. Zij hebben dit evenwel nagelaten'.

En nu?

'25. Het vorenstaande brengt mee dat de kopers redelijkerwijs niet mochten aannemen dat de tegeldemaking van het landgoed nodig was, en dat zij de executeur niet bevoegd konden achten om de erfgenamen aan de koopovereenkomst te binden.

26. Dat leidt ertoe dat de in rechtsoverweging 11 omschreven vraag, of de levering van het landgoed door de executeur aan kopers de met die levering beoogde overdracht heeft bewerkstelligd, ontkennend moet worden beantwoord, nu daarvoor een rechtsgeldige titel ontbreekt. Het landgoed moet derhalve geacht worden de nalatenschap nimmer te hebben verlaten, zodat de erfgenamen er eigenaar van zijn gebleven.'

Nimmer te hebben verlaten? We herkennen hier het beruchte causale stelsel: titel weg, eigendom weg. Civielrechtelijk even slikken.

Is het glas van de beheersexecuteur naar Nederlands recht wat de externe vertegenwoordigingsmacht betreft dan nog steeds (half) vol $^{9}$ of na het wijzen van dit arrest (half)leeg? Hoewel het kaartenhuisje van de eigendomsoverdracht uiteindelijk instort, betreft dit geen aanslag op de gevestigde positie van deze erfrechtelijke functionaris. Onder normale omstandigheden, oftewel 'in het algemeen', mag men de executeur in het rechtsverkeer nog steeds voor vertegenwoordigingsbevoegd houden bij het afwikkelen van de nalatenschap, waarbij een belangrijke rol speelt wat kopers 'redelijkerwijs' mochten aannemen.

Op de erfrechtelijke denkpiste zal men zich ongetwijfeld wel de vraag gaan stellen of deze transactie anders zou zijn afgelopen voor de erfgenamen indien de 'onbevoeg-

9. Ik spreek van 'half' omdat een tweesterrenexecuteur in het onroerendgoedverkeer nu eenmaal geen drie sterren heeft, oftewel een beheersexecuteur niet de bevoegdheden van een afwikkelingsbewindvoerder heeft, waardoor enige notariële voorzichtigheid uiteraard altijd gewenst is. de' executeur de koopakte zonder begeleiding, of zo men wil zonder het juridisch kompas van een notaris, tot stand had laten komen en zonder dat een ontsnappingsclausule was opgenomen. Zou het hof de koper dan in bescherming hebben genomen? ${ }^{10}$ Daar lijkt het op.

\section{Bijzondere omstandigheden}

Bij de vraag naar de betekenis van het onderhavige arrest mag ook aan het volgende niet voorbij worden gegaan. Er zijn in deze zaak enkele bijzondere omstandigheden, toeval of niet, die maken dat we de uitkomst van deze procedure niet op elke 'huis-tuin-en-keukenexecutele' kunnen plakken. We dienen ons immers te realiseren dat:

- het niet snel zal voorkomen dat de executeur op de dag dat de akte van levering wordt gepasseerd, wordt geschorst (en later ook ontslagen);

- een executeur niet altijd zal doorzetten tegen de wil van de erfgenamen; ${ }^{11}$

- de erfgenamen hebben laten weten dat zij de schulden van de nalatenschap (de vorderingen wegens overbedeling uit de wettelijke verdeling) niet zullen opeisen;

- de schuldeisers (!) tevens erfgenamen/eigenaren van het landgoed waren;

- er verder géén schulden van de nalatenschap zijn; ${ }^{12}$

- een koopovereenkomst vaak ook niet op een notariskantoor wordt aangegaan, met alle 'Belehrung' van dien, waardoor de (notariële) koper (sneller) op de hoogte is van eventuele onduidelijkheid rond de bevoegdheid van de executeur;

- (last but not least) in de koopakte alvast voor de executeur een recht op ontbinding wordt opgenomen voor de situatie dat hij deze ontbinding op grond van een rechterlijke uitspraak noodzakelijk acht. Een ontsnappingsclausule als notariële deus ex machina.

\section{Hof Amsterdam 22 december 2015, tuchtrechtelijk hoger beroep}

Terug naar de tuchtrechtelijke kijk in hoger beroep op het handelen van de notarissen. Ook Hof Amsterdam geeft op 22 december 2015, ECLI:NL:GHAMS: 2015:5551, allereerst een lesje burgerlijk recht:

'Voor overdracht van een onroerende zaak wordt vereist een levering krachtens geldige titel verricht door

10. Dit roept bij mij de oude discussie over de verplichte inschakeling van een notaris in de verbintenisrechtelijke 'voorfase' weer op.

11. Er had 'vormerkung' plaatsgevonden.

12. In Rechtspraak Notariaat, RN 2015/102, wordt in de Wenk bij het onderhavige arrest van 6 oktober 2015 opgemerkt: 'Niet vaak zal het immers voorkomen dat er geen schulden zijn ter voldoening waarvan goederen van de nalatenschap te gelde moeten worden gemaakt.' 
degene die bevoegd is over de onroerende zaak te beschikken (artikel 3:84 lid 1 BW). Het was aan notaris sub 1 om ter zake van de verkoop en levering van het landgoed onderzoek te doen naar de geldigheid van de titel (de koopovereenkomst) en de beschikkingsbevoegdheid van de partner als executeur.'

En een en ander toegespitst op de executeur, oftewel Boek 4 BW:

'Hierbij was van belang dat de partner als executeur enkel bevoegd was het landgoed te gelde te maken, voor zover dit nodig was om de schulden van de nalatenschap te voldoen, zoals volgt uit artikel 4:147 lid 1 BW. De notaris dient in een dergelijk geval te onderzoeken of tegeldemaking nodig is voor de betaling van schulden van de nalatenschap. In beginsel mag een notaris daarbij afgaan op de informatie die de executeur verstrekt over de baten en de schulden van de nalatenschap en de noodzaak van de tegeldemaking, tenzij de notaris gerede twijfel heeft of moet hebben over de juistheid van deze informatie.' (curs. BS)

Volgens mij ziet Hof Amsterdam hier over het hoofd dat de Hoge Raad het allemaal wat ruimer ziet en verkoopbevoegdheid ook op de beheersbevoegdheid kan worden gebaseerd, maar dat terzijde. Terug naar de casus en de analyse van het hof. Er waren volgens het hof serieuze signalen dat de klagers niet akkoord waren en vraagtekens zetten bij het optreden van de partner als executeur en vruchtgebruikster. En wat betekent dit in concreto?

'Deze omstandigheden tezamen met het feit dat klagers niet alleen schuldeisers maren van de nalatenschap, maar ook als erfgenamen van de nalatenschap eigenaren waren van het landgoed en daardoor een direct belang hadden bij het al dan niet vervreemden van het landgoed, hadden voor notaris sub 1 reden moeten zijn om nader onderzoek te doen naar de vraag of in dit geval voor de partner als executeur tegeldemaking van het landgoed van de erfgenamen noodzakelijk was voor het voldoen van schulden aan diezelfde erfgenamen. Dat onderzoek zou in dit geval erop neer zijn gekomen dat de notaris klagers zou hebben gevraagd of zij inderdaad hun vorderingen op de partner opeisten, ook als dat zou leiden tot verkoop en levering van het landgoed aan derden. Dat notaris sub 1 geen noodzaak zag om iets met de brief van 5 februari 2013 te doen, zoals hij ter zitting heeft verklaard, en onder genoemde omstandigheden zonder nader onderzoek heeft meegewerkt aan de voorbereiding van de verkoop en levering van het landgoed, acht het hof dan ook onbegrijpelijk en tuchtrechtelijk verwijtbaar. Dit klachtonderdeel zal gegrond worden verklaard.' (curs. BS)

In de betreffende brief van 5 februari 2013 heeft de advocaat van klagers onder meer geschreven dat een verzoekschriftprocedure zal worden gestart om de executeur te ontslaan. ${ }^{13}$

Het bijzondere van deze casus blijft de dubbelrol van klagers: schuldeiser van de nalatenschap én eigenaar/ erfgenaam. In het algemeen mag de notaris afgaan op de informatie die de executeur verstrekt over de activa en passiva van de nalatenschap en de noodzaak van de verkoop. In casu had hij gerede twijfel moeten hebben over de informatie. Nu de koopakte op het notariskantoor zou worden getekend onder begeleiding van de notaris, zou wellicht al een concept van de koopovereenkomst naar de erfgenamen gezonden dienen te worden. En niet alleen een ontwerp van de akte van levering. We dienen ons tevens te realiseren dat een en ander ook heel anders zou zijn gelopen als de koopakte 'op straat', buiten de notaris om, getekend zou zijn. Dan moest de notaris (al dan niet daartoe veroordeeld in kort geding) waarschijnlijk (verplicht) meewerken aan de levering en zou de koper waarschijnlijk beschermd worden. Kortom, de ene situatie is de andere niet.

Hof Amsterdam moest ook nog (tuchtrechtelijke) aandacht besteden aan het uitbetalen van de koopsom aan de executeur in het licht van de verzochte en op de dag van de levering uitgesproken schorsing:

'Het hof is van oordeel dat de partner niet bevoegd was om in hoedanigheid van executeur iets van de verkoopopbrengst te ontvangen, omdat zij op het moment van uitbetaling (met onmiddellijke ingang) al was geschorst als executeur. Dat de beschikking waarbij de partner van die taak was geschorst niet uitvoerbaar bij voorraad is verklaard, doet aan het voorgaande niet af, te meer daar op grond van artikel 676a, aanhef en onder e, Rv tegen beschikkingen tot schorsing (artikel 4:149 lid 2, tweede zin, BW) geen hoger beroep openstaat en het bovendien een voorlopige voorziening betreft. Dat onder de beschikking tot schorsing in weerwil van deze bepalingen en kennelijk per abuis anders is vermeld door de griffier kan daaraan niet afdoen. Bovendien diende notaris sub 2 rekening te houden met de mogelijkheid dat de partner als executeur in de nalatenschap van erflater zou worden ontslagen. Uit vorenbedoelde beschikking blijkt immers dat het verzoekschrift (onder meer tot schorsing van de partner als executeur) is ingediend om gedurende het onderzoek naar de vraag of de taak van de executeur dient te eindigen door ontslag (met onmiddellijke ingang) een aantal voorlopige voorzieningen te treffen. Verder was notaris sub 2 ervan op de hoogte, zie de brief van 26 april 2013 van mr. [X], dat een procedure zou worden gestart waarbij de bevoegdheid van de partner om als executeur tot tegeldemaking van het landgoed over te gaan zou worden aangevochten. Ook dit was een reden voor notaris sub 2 om de nodige terughoudendheid te

13. Klagers hebben geen vertrouwen meer dat de partner in staat is om de taken als executeur naar behoren uit te voeren en te volbrengen. 
betrachten in plaats van zonder enig voorbehoud tot doorbetaling van de verkoopopbrengst over te gaan. Dat notaris sub 2 onder deze omstandigheden (toch) aan de partner een deel van de verkoopopbrengst van het landgoed heeft uitbetaald, is hem dan ook tuchtrechtelijk te verwijten. Dit klachtonderdeel is eveneens gegrond.' (curs. BS)

Het hof komt dan ook tot de conclusie dat de notarissen in dit dossier onzorgvuldig hebben gehandeld en de belangen van klagers ernstig hebben veronachtzaamd, waardoor klagers nadeel hebben ondervonden. Het hof ziet derhalve aanleiding om aan de notarissen ieder de maatregel van berisping op te leggen.

Hoe nu verder op de notariële werkvloer, alles overziende, civielrechtelijk en tuchtrechtelijk?

\section{Op naar de derde ster}

De erflater die zo veel mogelijk wil voorkomen dat bij de afwikkeling van zijn nalatenschap een bevoegdheidsvraag, zoals in het arrest van 6 oktober 2015, wordt opgeworpen, doet er goed aan om een afwikkelingsbemind over de goederen van de nalatenschap in te (laten) stellen en de executeur tevens tot afwikkelingsbewindvoerder te (laten) benoemen. In dat geval is het glas helemaal vol. Te denken valt dan aan een tekst in de navolgende sfeer:

'De afwikkelingsbewindvoerder is bevoegd om over de goederen van mijn nalatenschap als vertegenwoordiger van de erfgenamen te beschikken, als ware hij enig rechthebbende en derhalve zonder medewerking/toestemming/machtiging/goedkeuring van welke aard dan ook, zulks met toepassing van het beginsel van zaaksvervanging. Dit mede met als doel een soepele boedelafwikkeling te garanderen.'

De koppeling aan het criterium schulden van de nalatenschap als bedoeld in artikel 4:147 BW maakt immers dat 'onroerend goed' niet gemakkelijk te gelde wordt gemaakt door een beheersexecuteur bij de afwikkeling van een nalatenschap, ook al hoeft hij op grond van de uiterste wil niet met de erfgenamen te overleggen. Dit is (indien gewenst) echter eenvoudig te verhelpen door in de testamentenpraktijk de executeur vaker uit te dossen met een op maat gesneden 'derde ster', zoals de hiervoor staande clausule of een variant daarop, waarbij die koppeling wordt losgelaten. ${ }^{14}$ Het is uiteraard maar een voorbeeldtekst. Door meer te werken met afwikkelingsbewind zal de executeur er de facto alleen maar sterker op worden.

Indien de erflater echter aangeeft dat wat hem betreft (bijvoorbeeld) het woonhuis vooral niet door de executeur te gelde moet worden gemaakt, is het het overwegen waard de onroerende zaak niet onder het beheer van

14. Zie voor het ingrediënt art. 4:171 BW. de executeur te laten vallen. Een ingreep (de andere kant uit) die mijns inziens in de testamentenpraktijk nog weinig voorkomt. Hoe zou erflater hebben gedacht over de verkoop van het landgoed? Als het koste wat kost in de familie moest blijven, had hij het ook kunnen legateren aan de kinderen (of aan een van hen) dan wel zijn wensen met betrekking tot het landgoed nog specifieker kunnen uitwerken in het testament. ${ }^{15}$

Het afwikkelingsbewind heeft in 2003, bij de komst van het nieuwe erfrecht, een valse start gekend. Hoezo? De oude schrik over de ongelukkige verhouding tussen executeurachtigen en legitimarissen zat er immers destijds nog goed in. Nog lang en vaak was in notariële kringen te horen dat de derde ster (het afwikkelingsbewind) een inferieure verkrijging opleverde. Dat klopt, ware het niet dat daarmee de bevoegdheid van de afwikkelingsbewindvoerder niet zou kunnen worden aangetast. Het inroepen van de legitieme moet immers verlopen via de 'contantenverklaring' als bedoeld in artikel 4:63 lid 3 $\mathrm{BW}$. Door het inroepen van de legitieme portie moesten de erfgenamen door vermerping ${ }^{16}$ het veld ruimen en niet meer de afwikkelingsbewindvoerders. Hun positie en bevoegdheid bleven overeind. De legitieme portie nieuwe stijl levert immers slechts een vordering in geld op, en geen vernietiging van bevoegdheden, maar dat is tegenwoordig (anders dan een jaar of tien geleden) gelukkig een erfrechtelijk feit van algemene bekendheid. De afwikkelingsbewindvoerder staat thans als een huis. Een aandachtspunt in de testamentenpraktijk blijft wel het duidelijk uitschrijven in de uiterste wil van de beoogde bevoegdheden van de afwikkelingsbewindvoerder, indachtig het blanco karakter van artikel 4:171 BW. ${ }^{17}$

\section{Ter afsluiting}

Ik sluit af met een kleine cri de coeur. Hoewel met de uitkomst van het arrest van Hof Arnhem-Leeuwarden van 6 oktober 2015 te leven is en (mede) door de woorden 'in het algemeen' het glas van de beheersexecuteur (half)vol blijft, had het wellicht ook anders gekund. Er had meer met de ontsnappingsclausule ${ }^{18}$ of onrechtmatige daad kunnen worden gedaan en nog meer de klemtoon gelegd kunnen worden op de bijzondere omstandigheden. Ook bij de in de tuchtrechtelijke dimensie gegeven rechtsregel van Hof Amsterdam van 22 december 2015 blijft het glas onder normale omstandigheden (half)vol en hoeft de notaris alleen (marginaal) te toetsen of de verkoop noodzakelijk is om de schulden van de

15. Wellicht had dit (het in de familie blijven) ook kunnen worden afgeleid uit het vruchtgebruiklegaat ten behoeve van de partner-executeur, quasi-stiefmoeder. De erfrechtelijke spanning was bij het lezen van de arresten voelbaar.

16. Anders in geval van aanvullende inkorting in geld.

17. Zie bijv. B.M.E.M. Schols, Van boedelberedderaar tot afwikkelingsbewindvoerder, WPNR 2015/7064.

18. Wel spreekt het hof onder punt 24 van 'meer in het bijzonder de preambule' en is er wel degelijk aandacht voor de clausule. 
nalatenschap te voldoen. In mijn dissertatie ${ }^{19}$ heb ik geprobeerd een voorzet in dezen te geven:

'Allereerst doet de notaris er goed aan om de "belehrde" executeur in de akte van levering en liefst reeds in de koopakte met zoveel woorden te laten bevestigen dat de reden van de verkoop was de voldoening van de schulden van de nalatenschap.'

En:

'De notaris vraagt ten behoeve van zijn dossier "door" naar bijvoorbeeld de boedelbeschrijving, een kopie van de successie-aangifte of aanslag, naar een overzicht van de legaten die uitgekeerd moeten worden, naar de berekening van de legitieme portie die moet worden uitgekeerd, afhankelijk van de betreffende letter van art. 4:7 BW.'

De notaris is civielrechtelijk en tuchtrechtelijk niet te benijden. We blijven dan ook achter met de vraag op wiens kompas de notaris zelf tijdens een dergelijke complexe erfrechtelijke tocht risicoloos zou kunnen varen. Waarschijnlijk op dat van de driesterrenexecuteur. Want een tweesterrenexecuteur doet het in het onroerend goed niet altijd even goed. 